PRACE GEOGRAFICZNE

zeszyt 154, 2018, 71-92

doi: $10.4467 / 20833113$ PG.18.008.8760

Instytut Geografii i Gospodarki Przestrzennej UJ

Wydawnictwo Uniwersytetu Jagiellońskiego

\title{
DYNAMIKA LUDNOŚCIOWA MIAST POLSKI I BIAŁORUSI - STUDIUM PORÓWNAWCZE
}

\author{
Liudmila Fakeyeva, Katarzyna Gorczyca, Andrzej Zborowski
}

\section{Population dynamics of Polish and Belarus cities - a comparative study}

\begin{abstract}
The development of settlement systems in Poland and Belarus has many common features such as intensive processes of industrialization and urbanization, a centrally planned development of cities, a rapid growth of importance of big cities in settlement systems. On the other hand, one can observe significant differences: a faster transition of Polish cities to the post-industrial phase, earlier deindustrialization and gentrification processes in large cities, advanced processes of decentralization and suburbanization, as well as socio-economic development of small and medium cities in metropolitan areas. The aim of the article is to explain the impact of metropolization processes on the demographic development of the urban settlement network in Poland and Belarus. Based on the population dynamics analysis in the period 1970-2014,trends characteristic for the settlement development processes in the researched countries were distinguished. The classification of population development of Polish and Belarusian urban centers was constructed, and 4 types of urban development were distinguished: population progression, moderate growth, depopulation, and shrinking. Both countries have a positive population dynamics in small urban centers within the boundaries of functional urban centers. However, in Poland we observe a decline in the population of the central city and a concentration of population in suburban centers, while in Belarus the impact of a large urban center (Minsk, Brest) does not lead to decentralization of the population in the core of a functional urban area. In the investigated countries, unfavorable demographic trends and the occurrence of dense areas characterized by depopulation were observed in peripheral cities as well as in post-industrial centers.
\end{abstract}

Keywords: settlement system, polycentric development, metropolisation, Poland, Belarus 
Zarys treści: Rozwój systemów osadniczych w Polsce i na Białorusi posiada wiele cech wspólnych: intensywne procesy uprzemysłowienia oraz urbanizacji, centralnie planowany rozwój miast, szybki wzrost znaczenia dużych miast w systemach osadniczych. $Z$ drugiej strony widoczne są znaczące różnice: szybsze przejście polskich miast do fazy postindustrialnej, wcześniejsze procesy deindustrializacji i gentryfikacji w dużych miastach, zawansowane procesy dekoncentracji i suburbanizacji oraz rozwój społeczno-ekonomiczny małych i średnich miast w obszarach metropolitalnych. Celem artykułu jest wyjaśnienie wpływu procesów metropolizacji na demograficzny rozwój miejskiej sieci osadniczej w Polsce i na Białorusi. Na podstawie analizy dynamiki liczby ludności w okresie 1970-2014 wyróżniono tendencje charakterystyczne dla procesów rozwoju osadniczego badanych krajów. Skonstruowano klasyfikację rozwoju ludnościowego ośrodków miejskich polskich i białoruskich oraz wyodrębniono 4 typy rozwoju miast: progresji ludnościowej, umiarkowanego wzrostu, depopulacyjny, kurczący się. W obu krajach zauważono występowanie dodatniej dynamiki ludnościowej w małych ośrodkach miejskich znajdujących się w granicach funkcjonalnych ośrodków miejskich. Jednak w Polsce obserwujemy zmniejszanie się liczby ludności miasta centralnego i koncentrację ludności w ośrodkach podmiejskich, natomiast na Białorusi oddziaływanie dużego ośrodka miejskiego (Mińska, Brześcia) nie prowadzi do dekoncentracji ludności w rdzeniu funkcjonalnego obszaru miejskiego. W badanych krajach niekorzystne tendencje demograficzne i występowanie zwartych obszarów charakteryzujących się depopulacją zaobserwowano w miastach peryferyjnych, także w ośrodkach poprzemysłowych.

Stowa kluczowe: system osadniczy, rozwój policentryczny, procesy metropolizacji, Polska, Białoruś

\section{Wprowadzenie}

Rozwój systemów osadniczych w Polsce i na Białorusi posiada wiele cech wspólnych, takich jak: intensywne procesy uprzemysłowienia oraz urbanizacji, centralnie planowany rozwój miast, szybki wzrost znaczenia dużych miast w systemach osadniczych. $Z$ drugiej strony widoczne są istotne różnice: szybsze przejście polskich miast do fazy postindustrialnej, wcześniejsze pojawienie się w Polsce niż na Białorusi procesów deindustrializacji, zachodzące zawansowane procesy dekoncentracji ludności i suburbanizacji oraz przyspieszony rozwój społeczno-ekonomiczny małych i średnich miast w obszarach metropolitalnych. Struktura systemu osadniczego badanych krajów różni się znacząco - Polska posiada policentryczny system osadniczy z dużymi miastami, oraz bogatą sieć małych miast, natomiast w przypadku Białorusi dominuje ośrodek centralny Mińska, z wyraźnie mniejszą rolą innych ośrodków regionalnych i dużych miast oraz z mniej liczną siecią miast średnich i małych.

Istotnym warunkiem zrozumienia przemian zachodzących w krajach postsocjalistycznych jest rozróżnienie pomiędzy okresem krótkoterminowym, w którym podstawowe zasady organizacji politycznej i gospodarczej są zmieniane; okresem średnioterminowym, w którym zachowania mieszkańców, zwyczaje i normy kulturowe są dostosowane do nowego środowiska i zaczynają wpływać na szersze zmiany 
społeczne; oraz okresem długoterminowym, w którym dochodzi do przemian m.in. w morfologii miejskiej (Sykora, Bouzarovski, 2012). Mając na uwadze długotrwały proces zachodzących przemian w strukturze miejskiej, w artykule skoncentrowano się na analizie dynamiki liczby ludności ośrodków miejskich zachodzących od lat 70. XX w. do czasów współczesnych.

Celem artykułu jest wyjaśnienie wpływu procesów metropolizacji na demograficzny rozwój miejskiej sieci osadniczej w Polsce i na Białorusi.

W pracy postawiono następujące pytania badawcze:

- Jak zmieniała się rola ośrodków centralnych sieci osadniczej w Polsce i na Białorusi?

- Jaki jest wpływ procesów metropolizacji na tendencje rozwoju ludnościowego małych i średnich miast w Polsce i na Białorusi?

- Jakie są główne cechy i kierunki transformacji miejskiej sieci osadniczej w Polsce i na Białorusi?

Proces metropolizacji jest dominującym czynnikiem kształtującym systemy osadnicze, rozpatrywanym w różnych skalach, począwszy od globalnych po lokalne. Proces ten trwa od dawna, a jego nowe funkcje i znaczenie wynikają ze zmienionych uwarunkowań związanych z rozwojem cywilizacji technicznej oraz globalizacji zjawisk społeczno-gospodarczych (Markowski, Marszał 2006). Procesom globalizacji towarzyszy relokalizacja przemysłu i inwestycji, co prowadzi do nowej specjalizacji regionów. Wzrost roli rozwoju regionalnego jest przyczyną globalno-lokalnego dialektyzmu (Dicken 1994; Conti 1997). Kształtuje to ośrodki metropolitalne powiązane ze sobą z jednej strony siecią przepływu kapitału i informacji (Sassen 2001), a z drugiej strony - stagnacją lub słabym rozwojem miast położonych w obszarach inter-metropolitalnych oraz w regionach peryferyjnych (Storper, Scott 1992; Amin, Thrift 1994). Stopniowy rozwój regionu metropolitalnego na tle przemian demograficznych powoduje z reguły zmiany w przestrzenno-funkcjonalnym układzie regionu metropolitalnego - przejście od układu monocentrycznego do policentrycznego (Champion, 2001). Koncentracja ludności w obszarach metropolitalnych jest jednym z czynników kształtowania się metropolii, towarzyszy temu proces rozprzestrzeniania się ludności w jej obrębie i powstawania różnych stref działalności miejskiej (Smętkowski i in. 2009). Proces ten rozpatrywany jest jako faza rozwoju regionu miejskiego (Zborowski i. in. 2011).

Przemiany zachodzące w systemie osadniczym Polski i Białorusi zbadano w oparciu o fazy i stadia cyklu miejskiego według ujęcia modelowego (Klaassen, Scimeni 1981; Berg van den i in. 1982). Fazy rozwoju określone są na podstawie rozwoju liczby ludności miasta centralnego i jego rdzenia, które tworzą funkcjonalny obszar miejski (FUR). W modelu tym zakłada się 4 stadia rozwoju regionów miejskich: urbanizacji, suburbanizacji, dezurbanizacji, reurbanizacji; lub: koncentracji, dekoncentracji, dyspersji i rekoncentracji (Zborowski 2005). Na szczeblu krajowym można wyróżnić trzy odrębne stadia kształtowania się systemów miejskich. Stadium 
pierwsze charakteryzuje ekspansja miast naczelnych, stadium drugie - formowanie się subsystemów miast wokół miast średnich, stadium trzecie - wzrost małych miast. Ewolucja systemów miejskich prowadzi więc do dekoncentracji ludności i jej redystrybucji. Obserwuje się przesuwanie ludności w dół hierarchii miast, jak i przekształcanie obszarów wiejskich w miejskie (Domański 2006). Proces ten jest traktowany w dużej mierze jako konsekwencja przemian urbanizacyjnych w nawiązaniu do poszczególnych stadiów urbanizacji. W artykule omówiono przemiany ośrodków miejskich w odniesieniu do faz rozwoju zachodzących w badanych krajach, począwszy od urbanizacji „właściwej”, poprzez suburbanizację, do dezurbanizacji.

W Europie Środkowej przemiany zachodzące w okresie transformacji systemowej mają istotne znaczenie w kształtowaniu rozwoju miast oraz rozwoju demograficznym regionów miejskich. Prace porównawcze różnych krajów Europy Środkowowschodniej pokazujące na wspólnym tle historycznym dywersyfikację rozwoju miejskiej sieci osadniczej po przejściu transformacji systemowej były prowadzone przez: Steinführer, Haase 2007; Mykhnenko i Turok 2008; Kabisch i in. 2012; Kroll i Kabisch 2012; Rink i in. 2014.

\section{Badanie sieci osadniczej w Polsce}

W krajach Europy Środkowej warunki geopolityczne związane z upadkiem bloku wschodniego, transformacji społeczno-gospodarczych, a także wstąpienia Polski do UE, doprowadziły do powstania nowego modelu centrum-peryferia. Czynniki te mają podstawowe znaczenie w kształtowaniu rozwoju i procesów demograficznych w polskich miastach (Zborowski i in. 2012).

Przemiany systemu osadniczego Polski w okresie transformacji były przedmiotem badań w wielu aspektach, w tym analizy zmian w strukturze ludnościowej miast polskich (Szymańska, Grzelak-Kostulska 2005 a, 2005 b; Długosz 2005; Kurek 2005).

Ważnym problemem rozwojowym, a tym samym i problemem badawczym, stały się miasta kurczące się, w tym także małe i średnie ośrodki miejskie (Kantor-Pietraga i in. 2012). Badania depopulacji były prowadzone od lat 80 . XX w. i początkowo dotyczyły głównie obszarów wiejskich (Eberhardt 1989; Potrykowska 1989). Jednak na początku XXI w. zaczęto dostrzegać także problem wyludniania się polskich miast (Parysek 2005; Bieńkowska 2013; Zborowski i in. 2012; Kantor-Pietraga 2014).

\section{Badanie sieci osadniczej na Białorusi}

Badania przyczyn i następstw urbanizacji, zmian systemu osadniczego pod wpływem tego procesu na Białorusi badano od lat 60. XX w. (Rakow 1969; Rakow 1974; Medwedew, Polskiy 1969; Sidorow, Maksimow 1966; Maksimow 1972). Studia 
związane z ruchem naturalnym ludności miejskiej prowadziła Shakhotska (1975, 1985). Na początku lat 70. powstały prace dotyczące roli Mińska w systemie osadniczym, czynników jego rozwoju i wpływu na otaczające tereny (Polskiy 1973; Polskiy 1976, Gurin 1984).

Po zakończeniu stadium intensywnej urbanizacji powstają pierwsze kompleksowe opracowania geograficzne o transformacji miejskiego systemu osadniczego na Białorusi, czynników kształtujących charakter i przestrzenne cechy rozwoju tego procesu na różnych poziomach hierarchii terytorialnej - od poziomu kraju do poziomu poszczególnych ośrodków miejskich (Pirozhnik 2000; Pirozhnik, Antipova 2006, 2013; Manak 1992; Manak, Antipova 1999, Krasowski 2004, 2006; Antipova, Fakeyeva 2012).

\section{Metodologia, źródła danych}

W celu wypracowania klasyfikacji miast do zbudowania dynamicznego modelu rozwoju ludnościowego miast polskich i białoruskich przeprowadzono analizy statystyczne ośrodków miejskich. Jedną z najczęściej stosowanych metod określenia klasyfikacji miast jest hierarchiczna analiza skupień (Runge 2007; Miszewska1998). Autorzy przeprowadzili analizę skupień dla miast polskich i białoruskich, jednak wynik klasyfikacji nie spełnił przyjętego celu badawczego ze względu na duże zróżnicowanie trajektorii rozwoju miast. W związku z tym do zbudowania klasyfikacji ośrodków miejskich zastosowano metodę autorską z wykorzystaniem analitycznego połączenia dynamiki ludności miast na tle etapów rozwoju społeczno-ekonomicznego badanych krajów oraz etapów industrializacji i urbanizacji.

Okresy badawcze zostały podzielone na równe przedziały czasowe, 10-letnie (1970-2009) oraz dodano współczesny okres badawczy 2009-2014. Ze względu na umożliwienie porównywalności danych korzystano przede wszystkim z wyników spisów powszechnych. W przypadku różnicy w okresie przeprowadzania spisu w Polsce i na Białorusi, przekraczającej 1 rok, korzystano z danych ze statystyk bieżących roku najbliższego do przedłużenia równych 10-letnich okresów badawczych - 1999 i 2009.

W celu klarownego przedstawienia omawianych przemian rozwoju ludnościowego miast polskich i białoruskich zaproponowano typologię dynamiki liczby ludności w grupach miast. Wyróżniono 4 główne typy zmian liczby ludności. Typy A i B charakteryzowały się wzrostem ludności w całym badanym okresie, z kolei typy C i D cechował ubytek ludności. Typ A (progresji ludnościowej) charakteryzuje się stałym wzrostem liczby ludności w całym okresie badawczym. W typie A mamy zachowaną dodatnią dynamikę ludności w całym okresie badawczym z zachowaniem stałego trendu wzrostu. 
W miastach określonych jako typ B (umiarkowanego wzrostu) zanotowano ogólnie dodatnią dynamikę przyrostu liczby ludności w okresie 1970-2014, jednak w poszczególnych podokresach międzyspisowych występowała ujemna dynamika przyrostu ludności miejskiej. Tak więc ogólna dynamika jest dodatnia, ale zachowane widoczne są różnice w badanych podokresach spisowych. W związku z tym, typ B został podzielony na 4 podtypy na podstawie analizy trendów dynamiki. Wyodrębniono 4 typy trendów: 1) rozwijający się (podtyp B1), który charakteryzuje się spadkiem ludności na początku badanego okresu z późniejszym wzrostem; 2) regenerujący się (podtyp B2) - charakteryzujący się intensywnym rozwojem w pierwszej części okresu badawczego, następnie załamaniem, a obecnie dodatnią dynamiką, 3) zmienny (podtyp B3) - charakteryzujący się naprzemienną dynamiką rosnącą i malejącą 4) stagnujący (podtyp B4) - ze wzrostem liczby ludności na początku badanego okresu i późniejszym spadkiem.

Typ C (depopulacyjny) charakteryzował się ogólnym ubytkiem ludności w okresie 1970-2014. W typie C mamy ogólną dynamikę ujemną, jednak ze względu na zróżnicowanie w poszczególnym podokresach został podzielony na podtypy: 1) rozwijający się (podtyp C1), ze spadkiem ludności na początku badanego okresu i z późniejszym wzrostem; 2) regenerujący się (podtyp C2) - charakteryzujący się intensywnym rozwojem w pierwszej części okresu badawczego, następnie załamaniem, a obecnie dodatnią dynamiką, 3) o zmiennym trendzie spadku (podtyp C3) - charakteryzujący się naprzemienną dynamiką rosnącą i malejącą 4) kurczący się (podtyp C4) - ze wzrostem liczby ludności na początku badanego okresu i późniejszym spadkiem.

Typ D (kurczący się) stanowiły miasta, w których od lat 70. XX w. występował ubytek liczby ludności ze stałą dynamiką ujemną. Typ D charakteryzuje ujemna dynamika ludnościowa w całym okresie badawczym z zachowaniem stałego trendu spadku.

Miasta, które otrzymały (lub odzyskały) prawa miejskie w okresie 1970-2009 zostały zakwalifikowane do poszczególnych typów i podtypów, biorąc pod uwagę dynamikę rozwoju w okresie istnienia ośrodka jako miejskiego. Miasta, które otrzymały (lub odzyskały) prawa miejskie po 2009 r. nie zostały zakwalifikowane do żadnego z typów ze względu na zbyt krótki okres badawczy.

\section{Analiza porównaweza rozwoju miejskich systemów osadniczych w Polsce i na Białorusi w II połowie XX i na początku XXI w.}

Transformacja procesów urbanizacji w Polsce rozpoczęła się blisko dekadę wcześniej niż na Białorusi. Liczba ludności miejskiej przekroczyła 50\% w Polsce w 1966 r., a na Białorusi dopiero w 1976 r. Wzrost wskaźnika urbanizacji na Białorusi był 2 razy 
większy niż w Polsce, wynikało to z wcześniejszego i dłuższego okresu urbanizacji w Polsce. W Polsce od lat 90. XX w. udział wskaźnika urbanizacji był na stałym poziomie, natomiast na początku XXI w. zaobserwowano trend malejący i niewielki spadek udziału liczby ludności miejskiej w ogólnej liczbie ludności (z 61,8\% w 1999 r. do 60,3\% w 2014 r.). Spadek wskaźnika urbanizacji w Polsce wynika z przechodzenia polskich miast $\mathrm{z}$ fazy urbanizacji w fazę suburbanizacji. Zwróciła na to uwagę Jakóbczyk-Gryszkiewicz - zamożniejsi mieszkańcy miast zaczęli przenosić się do stref podmiejskich, gdzie przyciągały ich atrakcyjniejsze przyrodniczo tereny, niższe ceny gruntów i koszty budowy domów (Jakóbczyk-Gryszkiewicz 2011).

$\mathrm{Na}$ Białorusi utrzymuje się stały trend rosnący (udział ludności miejskiej w ostatnim okresie badawczym przekroczył 76,8\%), co w rezultacie powiększa różnice w poziomie urbanizacji badanych krajów (ryc. 1). Poziom wzrostu wskaźnika

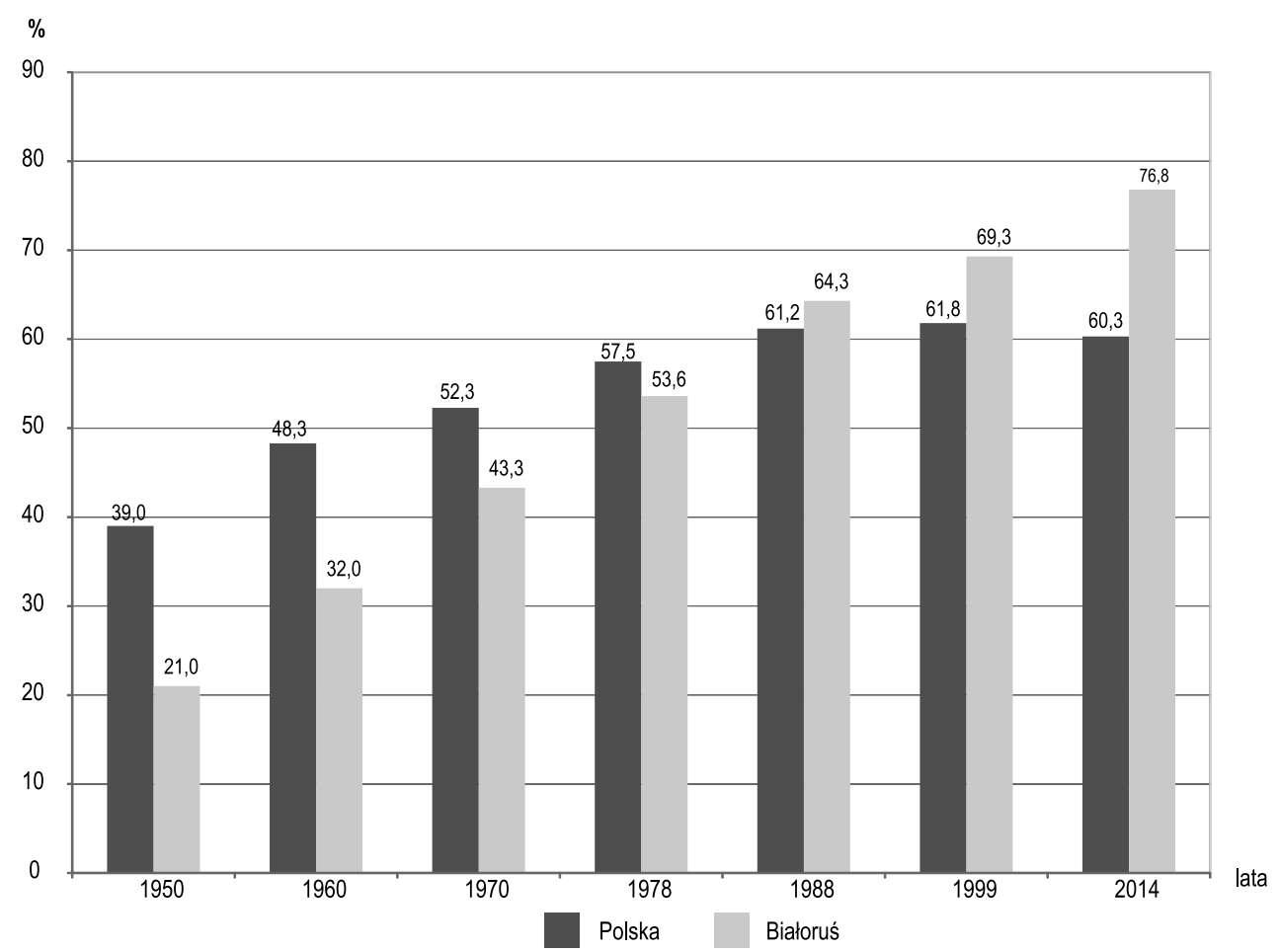

Rys. 1. Dynamika wskaźnika urbanizacji w latach 1950-2014 w Polsce i na Białorusi w \% Fig. 1. Dynamics of urban population share in Poland and Belarus, 1950-2014 (\%) Źródto: opracowanie własne na podstawie danych GUS i NSK.

Source: authors' compilation based on GUS and NSC data. 
urbanizacji na Białorusi był najszybszy w latach 1960-1970, wynikało to z intensywnej industrializacji w tym okresie. Od lat 80 . trend wzrostu był mniej intensywny.

Sieć osadnicza w Polsce i na Białorusi kształtowała się przez ponad 1000 lat pod wpływem różnych czynników: geograficznych, historycznych i społeczno-ekonomicznych. Różnica wpływu wymienionych czynników w regionach badanych krajów jest przyczyną nierównomiernego rozmieszczenia ludności miejskiej.

Na Białorusi ludność miejska jest rozmieszczona bardzo nierównomiernie, co ma swoje odzwierciedlenie już na poziomie regionów. Najbardziej zurbanizowanymi częściami kraju są tereny centralnej i wschodniej Białorusi. Najniższy poziom urbanizacji charakteryzuje tereny południowo-zachodniej części kraju (ryc. 2; ryc. 4). Region Mińska w 2014 r. zamieszkiwało aż 37\% ogółu ludności miejskiej Białorusi, z czego zdecydowana większość jest skoncentrowana w mieście stołecznym. Ludność Mińska wynosi 1922 tys. osób w 2014 r. i koncentruje 26\% ludności miejskiej kraju.

W Polsce ludność miejska rozmieszczona jest bardziej równomiernie (ryc. 3; ryc. 4), największy odsetek ludności miejskiej zamieszkuje województwo śląskie

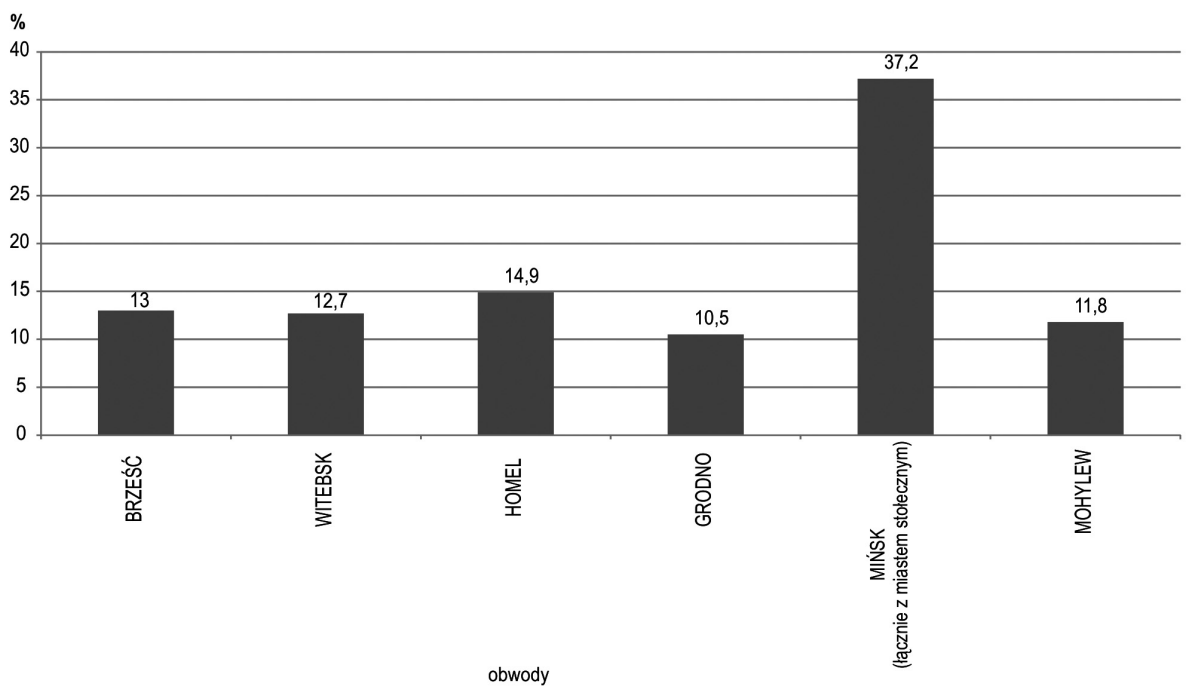

Rys. 2. Regionalne rozmieszczenie ludności miejskiej na Białorusi w 2014 r. w \%

Fig. 2. Regional distribution of urban population in Belarus in 2014 (\%)

Źródto: opracowanie własne na podstawie danych NSK.

Source: authors' compilation based on NSC data. 


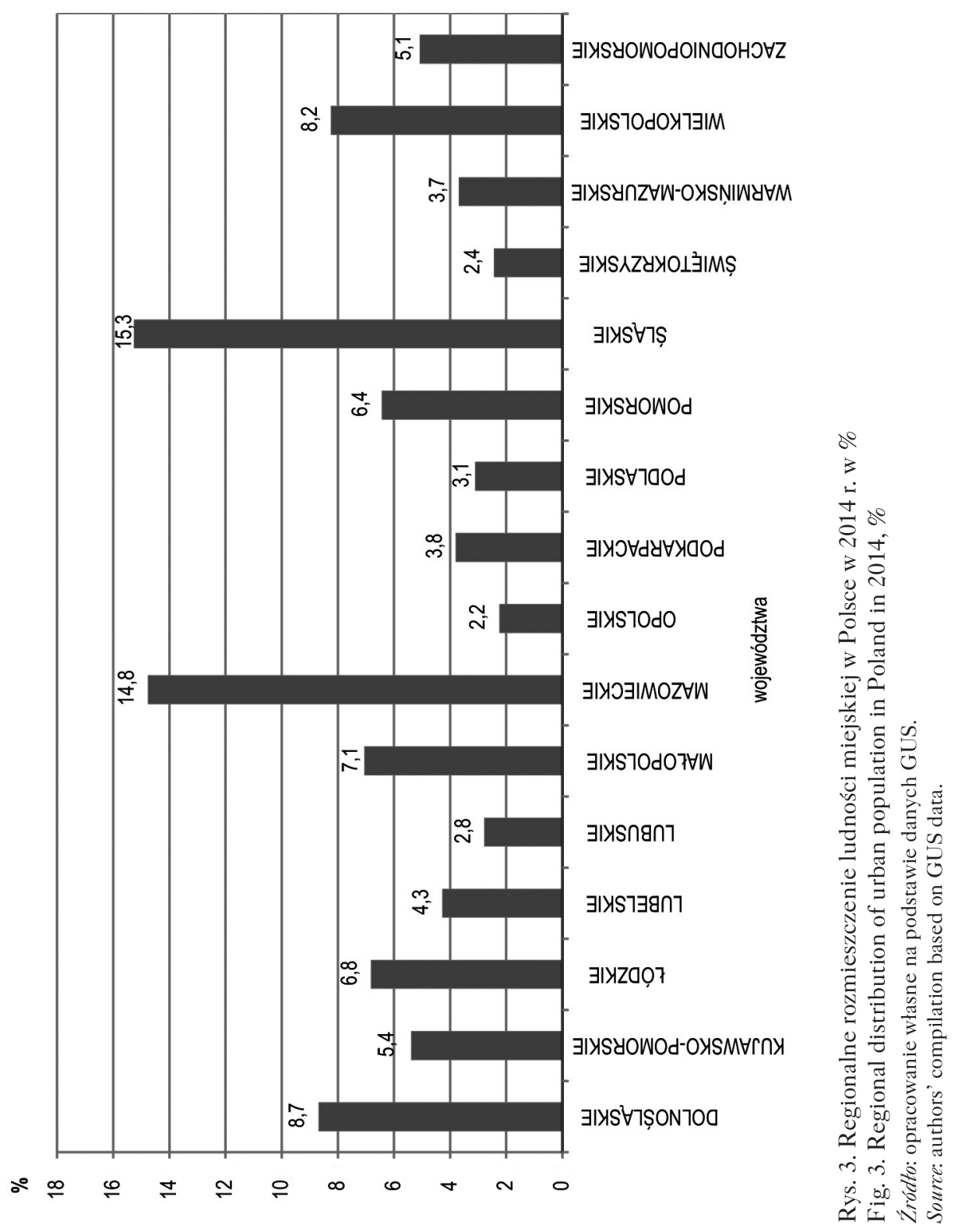




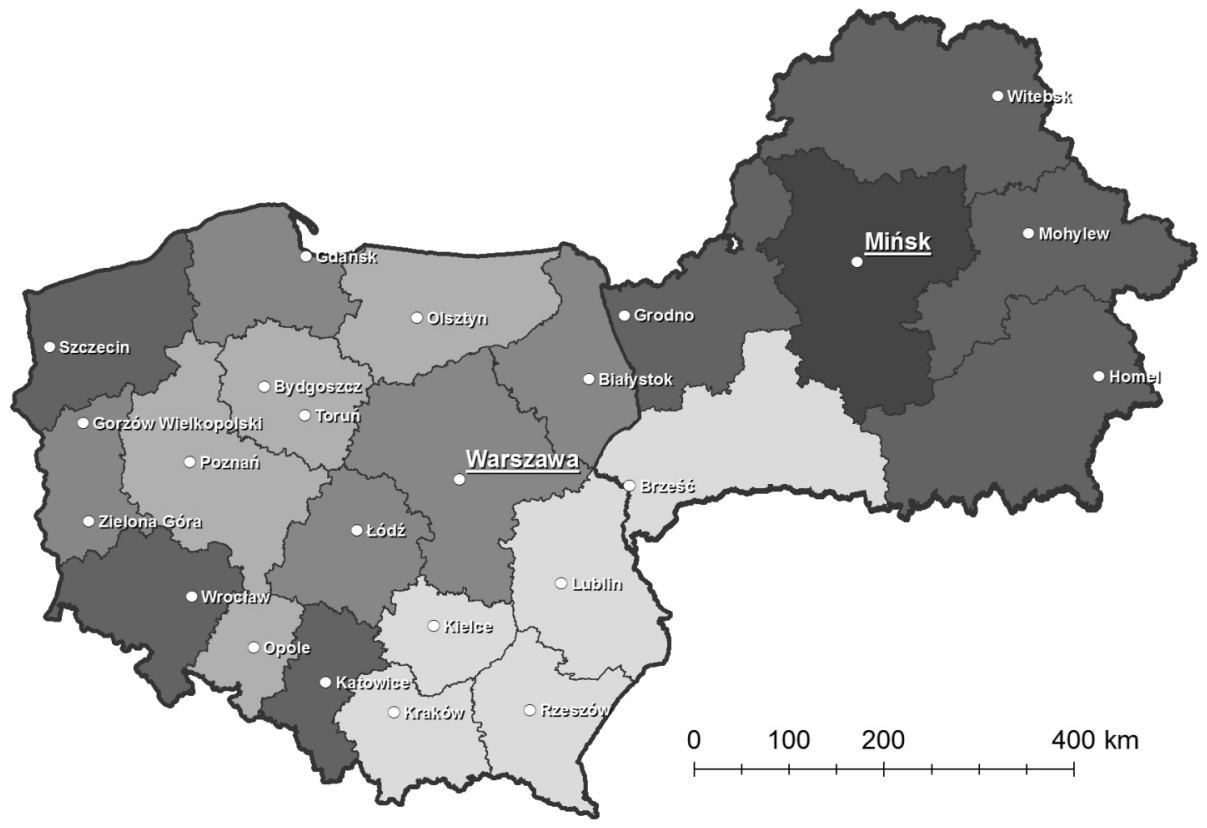

\footnotetext{
Granica państwa

Granica województwa / Granica obwodu

Miasto wojewódzkie / Centrum obwodu

Werszzelyel Miasto stoleczne
}

Udział ludności miejskiej w \% w ogóle liczby ludności według regionów

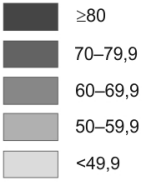

Rys. 4. Udział ludności miejskiej według regionów w Polsce i na Białorusi, 2014 r.

Fig. 4. Urbanization of regions in Belarus and Poland, 2014

Źródto: Opracowanie własne na podstawie danych z GUS i NSK.

Source: authors' compilation based on GUS and NSC data. 
$(15,3)$ oraz mazowieckie $(14,8)$. Znaczący odsetek ludności miejskiej występuje również na terenach województw dolnośląskiego $(8,7)$ i wielkopolskiego $(8,2)$, co wynika z większej gęstości sieci osadniczej w zachodniej części Polski. W pozostałych województwach udział ludności miejskiej nie przekraczał $8 \%$ i najniższy był w opolskim $(2,2 \%)$, świętokrzyskim $(2,4 \%)$ i lubuskim $(2,8 \%)$.

W Polsce najbardziej zurbanizowane są tereny województwa śląskiego (77\%) oraz zachodnia część kraju - województwa dolnośląskie i zachodniopomorskie przekraczają 65\% udziału ludności miejskiej. Najsłabiej zurbanizowane są tereny południowo-wschodniej Polski; w województwach podkarpackim, świętokrzyskim, lubelskim i małopolskim wciąż udział ludności wiejskiej przekracza 50\%. Takie rozmieszczenie ludności miejskiej w dużym stopniu wynika z uwarunkowań historycznych.

Różnice w poziomie urbanizacji pomiędzy zachodnią i wschodnią częścią Białorusi są określone czynnikami historycznymi i społeczno-ekonomicznymi. Proces industrializacji rozpoczął się wcześniej i zachodził gwałtowniej w tej części Białorusi, która wchodziła w skład Związku Radzieckiego do 1939 r. (Klunia 2000). Duże miasta przemysłowe zaczęły się rozwijać jeszcze w okresie przedwojennym (Witebsk, Orsza, Mohylew, Bobrujsk, Homel); natomiast na zachodzie Białorusi duże ośrodki przemysłowe powstały dopiero po wojnie. Proces intensywnej industrializacji zachodniej części kraju rozpoczął się w latach 60. XX w. Urbanizacja zachodniej części Białorusi była późniejsza i wolniejsza nie tylko z powodów historycznych, lecz także wynika z wyższego poziomu rozwoju gospodarki rolnej i większej trwałości wiejskiej sieci osadniczej. W związku z tym małe miasta w zachodniej części Białorusi odgrywają znaczną rolę w systemie osadnictwa miejskiego.

W Polsce rozwój miejskiej sieci osadniczej kształtowały również w wysokim stopniu procesy historyczne, w szczególności przemiany społeczno-gospodarcze zachodzące po II wojnie światowej. Tempo rozwoju było różne w zależności od regionu Polski, na przykład w latach 1950-1960, kiedy wyraźnie preferowano rozwój przemysłu ciężkiego i wydobywczego, największą dynamiką rozwoju demograficznego cechowały się miasta, których podstawą gospodarki był przemysł ciężki i wydobywczy (głównie dotyczy to miast Polski Południowej) oraz miasta położone na Ziemiach Odzyskanych (Szymańska, Matczak 2002).

Szybka koncentracja ludności w dużych miastach Polski była charakterystyczna dla lat 1950-1970, a w późniejszym okresie tempo koncentracji ludności miejskiej zmniejszyło się. Proces dekoncentracji ludności miejskiej rozpoczął się pod koniec lat 90., kiedy udział ludności miejskiej zaczął spadać od poziomu 62\% w 1990 r. do 60\% w 2014 r. Również udział ludności miejskiej w dużych ośrodkach miejskich (tj. miastach przekraczających 100 tys. mieszkańców) zaczął spadać z 50\% w 1990 r. do $46 \%$ w 2014 r., co było wynikiem postępującego procesu suburbanizacji. 
Struktura miejska osadnicza w Polsce charakteryzuje się większą stabilnością niż na Białorousi. Już w latach 60. duże miasta (>200 tys. mieszkańców) odgrywały istotną rolę i koncentrowały $1 / 3$ ludności miejskiej w Polsce oraz 1/5 ludności miejskiej na Białorusi (ryc. 5). Od lat 60. do 80. w Polsce udział mieszkańców w poszczególnych grupach miast nie uległ zasadniczym zmianom. Odnotowano podobny udział liczby ludności w miastach małych, średnich i dużych. Natomiast na Białorusi od lat 70. zaobserwowano zmniejszanie się liczby ludności miast małych (poniżej 20 tys. mieszkańców) na tle szybkiego wzrostu miast dużych (powyżej 100 tys. mieszkańców) (ryc. 6). Było to spowodowane gwałtowną industrializacją w tamtym okresie i migracją do dużych miast ludności wiejskiej oraz mieszkańców małych miast. W Polsce w latach 80. i 90. zauważono wzrost znaczenia miast dużych oraz przyrost ludności w miastach powyżej 200 tys. mieszkańców na tle stabilności i stagnacji w pozostałych grupach miast. W dużych miastach Polski od 2000 r. rozpoczął się proces dekoncentracji i spadku udziału ludności miast dużych. Na Białorusi zachowuje się tendencja koncentracji ludności w dużych miastach w całym okresie badawczym i w ostatnim okresie spisowym w miastach powyżej 200 tys. mieszkańców skoncentrowana była ponad połowa ludności miejskiej kraju. Dotyczy to ośrodków miejskich, które pełnią role stolicy lub centrum obwodu (oblast).

Polska charakteryzuje się większą stabilnością w strukturze osadniczej małych miast w stosunku do Białorusi. Cechą wspólną jest stabilność małych miast od 10 do 20 tys. mieszkańców, największa różnica powstaje w przypadku miast najmniejszych (do 5 tys. mieszkańców). W latach 1960-1970 trajektoria rozwoju miast małych była podobna, w obu krajach w tej grupie miast udział wskaźnika zmniejszył się dwukrotnie. Od początku lat 80. XX w. w Polsce najmniejsze miasta zachowały około 4\% udziału ludności miejskiej. Natomiast na Białorusi od lat 60. XX w. udział ludności miejskiej miast małych systematycznie spada.

\section{Model dynamicznego rozwoju ludnościowego miast polskich i białoruskich - typologia}

W celu skonstruowania modelu dynamicznego rozwoju ludnościowego miast polskich opracowano typologię dynamiki liczby ludności w 4 głównych grupach miast (tab.1; ryc.7).

Typ A - progresji ludnościowej, a więc stałego wzrostu liczby ludności, wystąpił w miastach polskich (udział polskich miast typu A - 21\%) oraz miastach białoruskich (udział białoruskich miast typu A - 17\%). Wśród polskich miast grupy A występują: miasto stołeczne Warszawa oraz miasta wojewódzkie ściany wschodniej (Białystok, Rzeszów). W miastach typu A obserwujemy również występowanie dużej liczby ośrodków mniejszych, są to: miasta położone w obszarach metropolitalnych oraz małe 


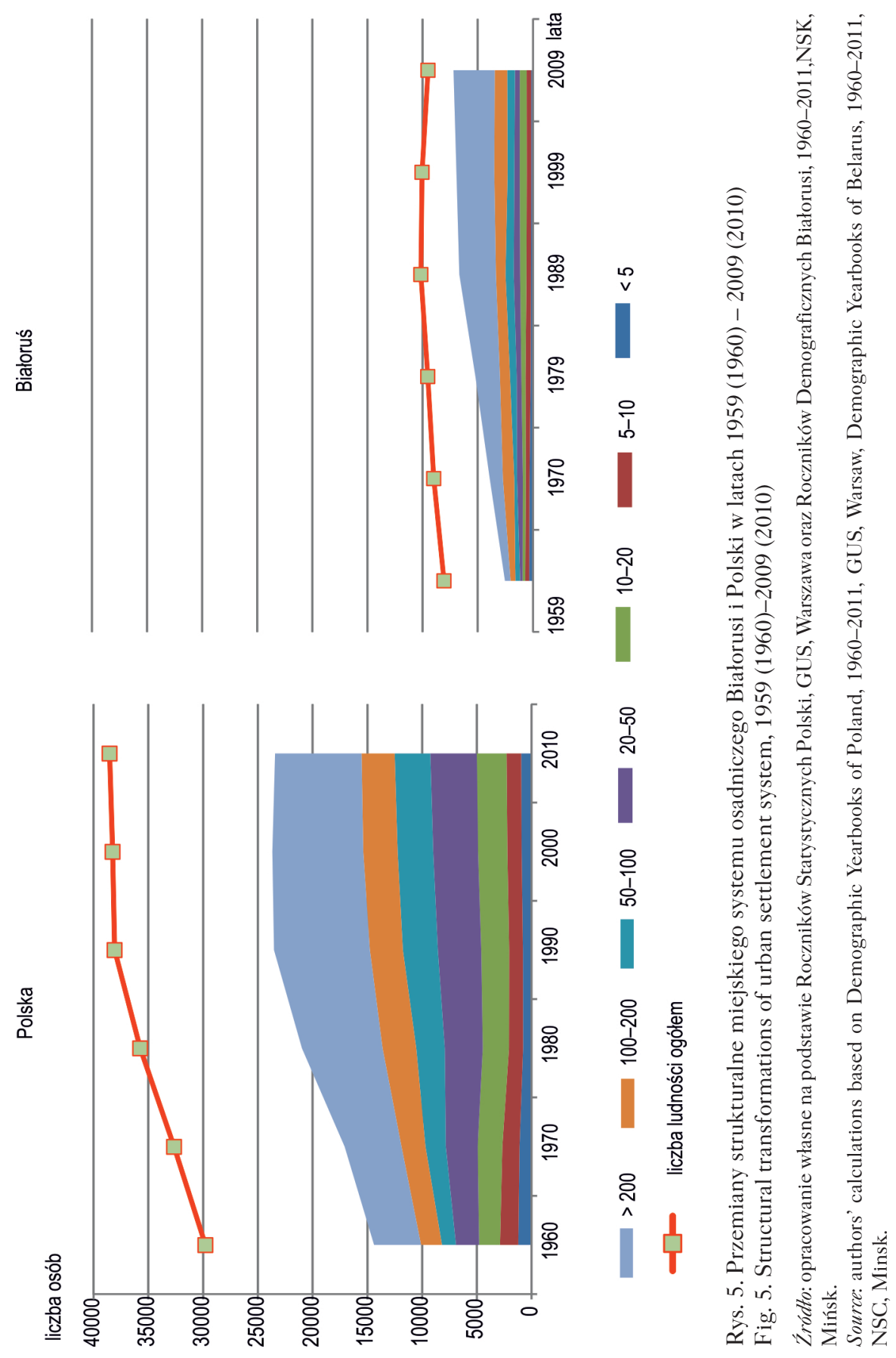



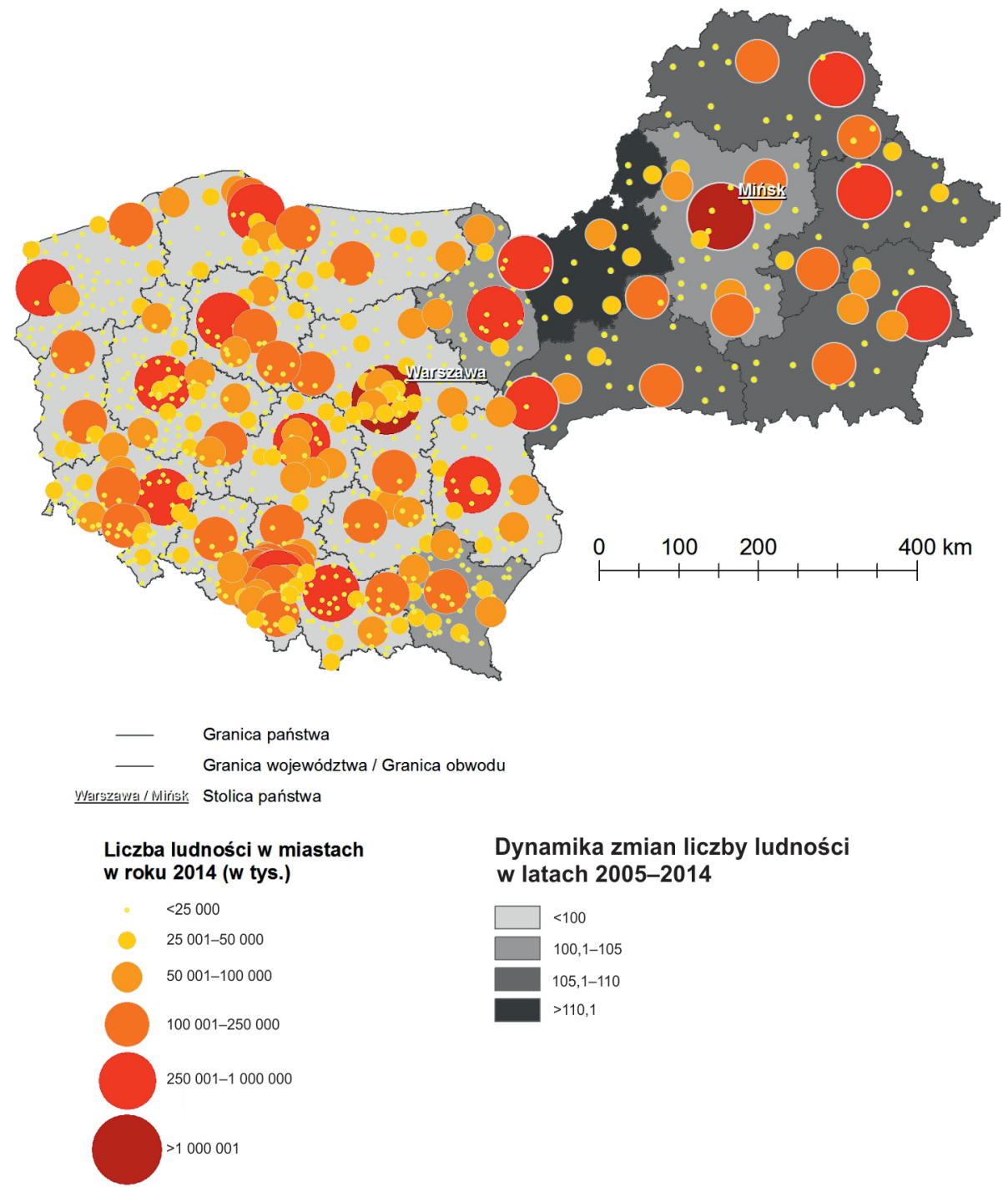

Ryc. 6. Dynamika zmian udziału ludności miejskiej w latach 2005-2014 w Polsce i na Białorusi w $\%$

Fig. 6. Dynamics of changes in the share of urban population in 2005-2014 in Poland and Belarus, in \%

Źródto: opracowanie własne na podstawie Roczników Statystycznych Polski, GUS, Warszawa oraz Roczników Demograficznych Białorusi, NSK, Mińsk.

Source: authors' calculations based on Demographic Yearbooks of Poland, GUS, Warsaw, Demographic Yearbooks of Belarus, NSC, Minsk. 


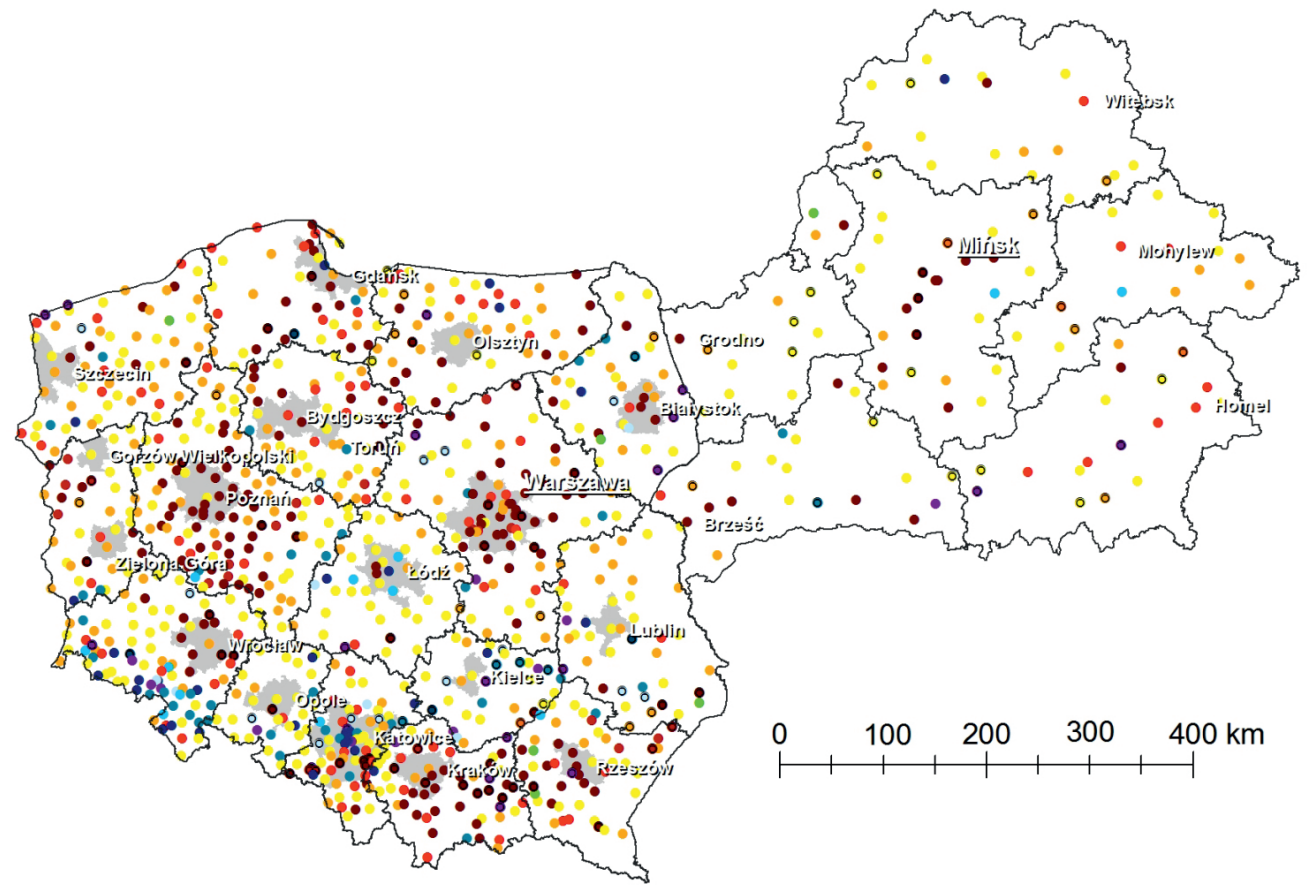

- Granica państwa

_ Granica województwa / Granica obwodu

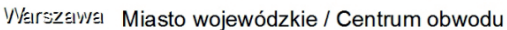

Granica funkcjonalnych ośrodków miejskich metropolitalnych i krajowych

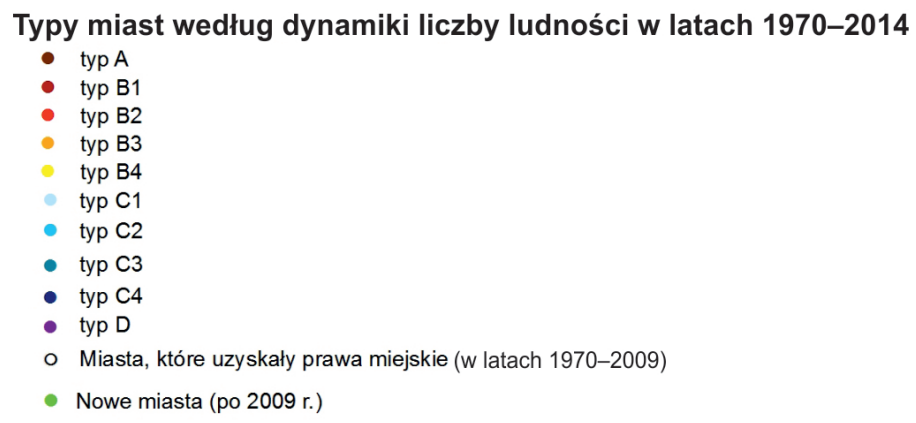

Ryc. 7. Typologia miast Polski i Białorusi wg wskaźnika dynamiki ludności w okresie 1970-2014

Fig 7. Typology of Polish and Belarus cities by the index of population dynamic in the period 1970-2014

Źródto: opracowanie własne na podstawie Roczników Statystycznych Polski, GUS, Warszawa oraz Roczników Demograficznych Białorusi, NSK, Mińsk.

Source: authors' calculations based on Demographic Yearbooks of Poland, GUS, Warsaw, Demographic Yearbooks of Belarus, NSC, Minsk. 
i średnie miasta położone poza obszarem metropolitalnym, na terenach z wyraźną funkcją rolniczą (Polska południowo-wschodnia), a także małe miasta Wielkopolski. Miasta progresji ludnościowej w Polsce koncentrują 20\% ludności miejskiej, natomiast na Białorusi skupiają połowę ludności miast (50\%). Wśród białoruskich miast typu A występują: miasto stołeczne Mińsk, regionalne centra zachodniej części Białorusi (Brześć, Grodno), rozwinięte ośrodki przemysłowe (Soligorsk, Żłobin, Żodzino, Baranowicze, Pińsk, Połock) oraz małe miasta w obszarach metropolitalnych Mińska (Dzierżyńsk, Smolewicze, Zasławl, Fanipal) i Brześcia (Żabinka). Nieliczne są przykłady małych miast stanowiących centra obszarów rolniczych (Stolin, Uzda, Nieśwież).

Miasta typu B (umiarkowanego wzrostu) stanowią największą grupę wszystkich analizowanych ośrodków miejskich, udział miast typu B w Polsce wynosi $63 \%$. Określane jako miasta akceleracji demograficznej w typie umiarkowanego wzrostu, tj. podtyp B1, stanowią 2,5\% ogółu miast. Są to wyłącznie małe miasta Polski, z których większość położona jest w obszarach metropolitalnych Warszawy (np. Podkowa Leśna, Milanówek) oraz małe miasta województwa wielkopolskiego i lubuskiego. Na Białorusi ten podtyp nie występuje.

Podtyp B2, przełomu demograficznego, charakteryzuje się intensywnym rozwojem w pierwszej części okresu badawczego, załamaniem w późniejszym okresie i dodatnią dynamiką, jest nieliczny i stanowi $9 \%$ ogólnej liczby polskich miast. Ta grupa ośrodków miejskich rozwinęła się w związku z zaawansowaniem wcześniej wykształconych funkcji w warunkach gospodarki rynkowej. Są to głównie miasta turystyczne i uzdrowiskowe, w których w okresie transformacji nastąpiło chwilowe załamanie dynamiki ludnościowej, a następie szybka regeneracja (Świnoujście, Zakopane, Malbork, Iwonicz Zdrój, Rymanów, Krynica Zdrój, Rabka Zdrój, Kalwaria Zebrzydowska, Bystrzyca Kłodzka, Łeba, Darłowo, Ustka, Wejherowo, Ustroń, Mikołajki).

Około 1/3 miast typu B należy do podtypu B3 i charakteryzuje się naprzemienną dynamiką rosnącą i malejącą, przy ogólnym dodatnim wskaźniku w całym okresie badawczym. Koncentrują one $20 \%$ ogółu ludności miejskiej w Polsce. Podtyp ten charakteryzuje się w miarę równomiernym rozmieszczeniem na terenie całego kraju.

W typie B około połowa miast mieści się w podtypie regresyjnym B4. Ze względu na dużą ilość ośrodków miejskich w tym podtypie możemy wyróżnić następujące zależności regionalne: 1) miasta średniej wielkości położone na ścianie wschodniej, w których ujemna dynamika występuje dopiero w ostatnim okresie badawczym (Biała Podlaska, Suwałki, Łańcut, Siedlce); 2) małe i średnie miasta województw: śląskiego, dolnośląskiego, opolskiego. Kształtowanie się w tych ośrodkach podtypu regresywnego wynikało z powodów historycznych. W latach 70. XX w. depopulacja była najbardziej widoczna na obszarach historycznego Górnego Śląska (część dzisiejszych województw śląskiego i opolskiego), gdzie powojenna fala migracyjna 
Tab. 1. Główne cechy wyznaczonych typów miast polskich i białoruskich

Table 1. Main features of designated types of Polish and Belarusian cities

\begin{tabular}{|c|c|c|c|c|c|c|c|}
\hline \multirow[t]{2}{*}{ Typy i podtypy miast } & \multirow{2}{*}{$\begin{array}{l}\text { Wskaźnik dynamiki ludności } \\
\text { w latach 1970- } 2014 \text { i typ } \\
\text { trendu }\end{array}$} & \multicolumn{2}{|c|}{ Liczba miast } & \multicolumn{2}{|c|}{$\begin{array}{c}\text { Udział liczby miast, } \\
\%\end{array}$} & \multicolumn{2}{|c|}{$\begin{array}{l}\text { Udział liczby ludno- } \\
\text { ści w miastach, \% }\end{array}$} \\
\hline & & Polska & Białoruś & Polska & Białoruś & Polska & Białoruś \\
\hline $\begin{array}{l}\text { Typ A - progresji } \\
\text { ludnościowej }\end{array}$ & \begin{tabular}{c|c}
$1970 \quad 2014$ \\
- \\
dodatnia dynamika, w \\
całym okresie badawczym \\
ze stałym trendem
\end{tabular} & 191 & 19 & 21,0 & 16,8 & 19,8 & 50,0 \\
\hline $\begin{array}{c}\text { Typ B - umiarkowanego } \\
\text { wzrostu }\end{array}$ & $\begin{array}{l}\text { dodatnia dynamika, w } \\
\text { całym okresie badawczym ze } \\
\text { zmiennym trendem }\end{array}$ & 572 & 85 & 62,8 & 75,2 & 68,9 & 49,0 \\
\hline $\begin{array}{l}\text { Podtyp B1 - akceleracji } \\
\text { demograficznej }\end{array}$ & $+{ }_{1970}^{+}$ & 23 & 0 & 2,5 & 0 & 0,6 & 0 \\
\hline $\begin{array}{l}\text { Podtyp B2 - przełomu } \\
\text { demograficznego }\end{array}$ & $\begin{array}{l}+{ }^{+} \\
- \\
1970\end{array}$ & 85 & 12 & 9,3 & 10,6 & 6,8 & 20,4 \\
\hline $\begin{array}{c}\text { Podtyp B3 - zmiennego } \\
\text { trendu }\end{array}$ & $\begin{array}{l}+\wedge \\
-1970\end{array}$ & 180 & 20 & 19,8 & 17,7 & 19,9 & 5,6 \\
\hline Podtyp B4 - regresywny & $\begin{array}{l}+ \\
- \\
1970\end{array}$ & 284 & 53 & 31,2 & 46,9 & 41,6 & 23,0 \\
\hline Typ C - depopulacyjny & $\begin{array}{l}\text { ujemna dynamika w całym } \\
\text { okresie badawczym ze } \\
\text { zmiennym trendem }\end{array}$ & 106 & 5 & 11,6 & 4,4 & 10,0 & 0,7 \\
\hline $\begin{array}{l}\text { Podtyp C1 - akceleracji } \\
\text { demograficznej }\end{array}$ & $-T_{1970}^{+}$ & 20 & 0 & 2,2 & 0 & 0,3 & 0 \\
\hline $\begin{array}{l}\text { Podtyp C2 - przełomu } \\
\text { demograficznego }\end{array}$ & $\begin{array}{l}+ \\
-\left.\right|_{1970}\end{array}$ & 10 & 2 & 1,1 & 1,8 & 0,3 & 0,4 \\
\hline
\end{tabular}




\begin{tabular}{|c|c|c|c|c|c|c|c|}
\hline $\begin{array}{c}\text { Podtyp C3 - zmiennego } \\
\text { trendu }\end{array}$ & $\underbrace{+}_{1970}$ & 44 & 2 & 4,8 & 1,8 & 1,7 & 0,3 \\
\hline Podtyp C4 - regresywny & $+\overbrace{1970 \quad 2014}^{+}$ & 32 & 1 & 3,5 & 0,9 & 7,7 & 0,02 \\
\hline Typ D - kurczący się & 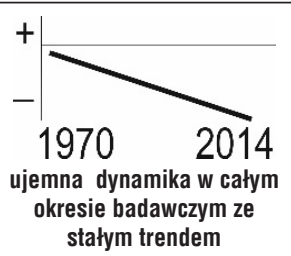 & 27 & 3 & 3,0 & 2,7 & 1,2 & 0,2 \\
\hline
\end{tabular}

*W tabeli nie uwzględniono 15 miast polskich (udział w liczbie miast 1,6\%, w liczbie ludności - 0,2\%) i jedno miasto białoruskie (udział w liczbie miast $0,9 \%$, w liczbie ludności - 0,1\%), które uzyskały prawa miejskie po 2009 r.

Źródto: opracowanie własne na podstawie Roczników Statystycznych Polski, GUS, Warszawa oraz Roczników Demograficznych Białorusi, NSK, Mińsk.

Source: authors' calculations based on Demographic Yearbooks of Poland, GUS, Warsaw, Demographic Yearbooks of Belarus, NSC, Minsk.

do Niemiec miała ograniczoną skalę, oraz w latach 70. w efekcie procesu tzw. łączenia rodzin, a także z uwagi na możliwości ekonomiczne, zaczęły się pierwsze fale wyjazdów do RFN (Kantor-Pietraga 2014); 3) miasta o silnym profilu przemysłowym (Tychy, Będzin, Zawiercie, Dąbrowa Górnicza) położone na terenach województwa śląskiego, charakteryzowały się gwałtownym wzrostem demograficznym do lat 70 . i stałym ubytkiem demograficznym od początku lat 80 . Wzrost w okresie industrializacji był na tyle gwałtowny, że ubytek w późniejszych okresach wpłynął na zmianę wskánnika dynamiki dla całego okresu badawczego 1970-2014 na ujemny.

$\mathrm{Na}$ Białorusi miasta typu B stanowią 69\% wszystkich ośrodków miejskich. Nie występuje podtyp B1 - miasta akceleracji demograficznej. Miasta umiarkowanego wzrostu podtypu przełomu demograficznego (B2) stanowią ośrodki położone w południowo-wschodniej części Białorusi. Można wymienić 3 rodzaje ośrodków miejskich: 1) miasta położone w obszarze, który ucierpiał w wyniki awarii w Czarnobylu (Wietka, Czeczersk), 2) duże miasta przemysłowe (Rzeczyca, Kalinkowicze), 3) wszystkie centra regionalne wschodniej części Białorusi (Mohylew, Witebsk, Homel). 
Miasta podtypu B3, charakteryzujące się zmiennym trendem demograficznym, stanowią 1/4 analizowanych ośrodków miejskich typu B, ale koncentrują zaledwie $6 \%$ ludności miast.

Miasta podtypu regresyjnego, tj. B4, stanowią 47\% wszystkich miast i tylko $23 \%$ udziału liczby ludności. Są to małe i średnie ośrodki rolniczo-przemysłowe oraz duże miasta przemysłowe (powyżej 100 tys. mieszkańców) położone głównie w północno-wschodniej części Białorusi (Orsza, Nowopołock, Gorki, Głębokie, Mołodeczno, Mścisław, Miadzioł, Wierchniedwińsk).

Typ C, tj. depopulacyjny, charakteryzujący się ogólnym spadkiem liczby ludności w latach 1970-2014 występuje w 106 ośrodkach miejskich Polski i 5 Białorusi.

Podtypy C1 (akceleracji demograficznej) i C2 (przełomu demograficznego) stanowią miasta, które zaczęły rozwijać się w latach 90. XX w. Regenerację obserwuje się w nielicznych małych miastach. Ze względu na stosunkowo małą liczbę ośrodków należących do tych podtypów nie można wyznaczyć wspólnego czynnika wpływającego na regionalne zróżnicowanie ośrodków miejskich.

Podtyp C3, tj. depopulacyjny o zmiennym trendzie, występuje w 44 polskich miastach. W większości są to małe ośrodki miejskie położone w południowej i zachodniej części kraju, miasta województwa dolnośląskiego, opolskiego, śląskiego. Jedyne miasto duże (> 100 tys. mieszkańców) należące do podtypu C3 to Zabrze. Podtyp C4 (regresyjny) liczy 32 miasta i koncentruje 7,7\% ludności. Występują tu zarówno duże i średnie ośrodki poprzemysłowe (Łódź, Wałbrzych, Świętochłowice, Ruda Śląska, Piekary Śląskie, Oświęcim, Bytom), jak i małe miasta turystyczne i uzdrowiskowe, które po załamaniu w okresie transformacji nie zregenerowały się (Nałęczów, Duszniki Zdrój, Polanica Zdrój, Lądek Zdrój, Szklarska Poręba). Znaczna część tych ośrodków położona jest w południowej i południowo-zachodniej części Polski.

Na Białorusi typ C, depopulacyjny, występuje tylko w 5 miastach, są to małe ośrodki miejskie położone peryferyjnie (Czerwień, Bychów, Janów, Kossowo, Dzisna).

Najbardziej niekorzystną dynamikę o stałym ubytku liczby ludności charakteryzuje typ D (kurczący się). Ze względu na długi okres badania, który generalnie cechuje intensywna urbanizacja krajów, typ D występuje w nielicznych przypadkach. W Polsce w tej grupie występuje 27 miast, w tym jedno duże miasto Chorzów i małe miasta peryferyjnie położone (Działoszyce, Kazimierz Dolny, Mogielnica, Wojcieszów, Jedlina Zdrój, Boguszów, Biała, Ćmielów). Na Białorusi typ D występuje w trzech małych peryferyjnych ośrodkach (Wasilewiczy, Turow, Dawid-Gorodok). Miasta typu D stanowią 1\% udziału ludności miejskiej w Polsce i 0,2\% na Białorusi. 


\section{Podsumowanie}

Na podstawie analizy dynamiki liczby ludności w latach 1970-2014 możemy wyróżnić pewne tendencje charakterystyczne dla procesów rozwoju osadniczego badanych krajów.

Pierwszą cechą charakterystyczną jest występowanie dodatniej dynamiki ludnościowej (tj. miast typu A - progresji ludnościowej i typu B - umiarkowanego wzrostu) w małych ośrodkach miejskich znajdujących się w granicach polskich funkcjonalnych ośrodków miejskich. Na Białorusi dodatnia dynamika ludnościowa występuje w małych miastach położonych wokół miast stanowiących centrum obwodu. Jednak szczególnie oddziaływanie dużego ośrodka miejskiego widać w przypadku Mińska i Brześcia, gdzie dominują ośrodki miejskie typu A. Zaobserwowano więc koncentrację liczby ludności, zarówno w mieście centralnym, jak i w ośrodkach podmiejskich położonych w granicach funkcjonalnego obszaru miejskiego. Przewagę małych miast charakteryzujących się typem dominacji ludnościowej zaobserwowano w obszarach metropolitalnych Warszawy, Krakowa, Poznania, Wrocławia, Rzeszowa, Białegostoku. W obszarach metropolitalnych Poznania, Wrocławia oraz Krakowa na początku XXI w. był obserwowany trend zmniejszania się liczby ludności miasta centralnego i koncentracji ludności w ośrodkach podmiejskich obszarów metropolitalnych. W 2014 r. tendencja ta utrzymywała się tylko w Poznaniu, przy nieznacznym „odbiciu demograficznym" miast centralnych Krakowskiego i Wrocławskiego Obszaru Metropolitalnego. Nieco podobna sytuacja występuje w obszarze Trójmiasta, gdzie miasta centralne (Gdańsk, Gdynia, Sopot) charakteryzują się zmniejszaniem się liczby ludności od początku XXI w., przy wzroście demograficznym małych ośrodków miejskich (Reda, Rumia, Pruszcz Gdański).

Drugą wspólną cechą charakterystyczną dla Polski i Białorusi jest występowanie umiarkowanego wzrostu w miastach położonych peryferyjnie i w ośrodkach poprzemysłowych. W granicach funkcjonalnych ośrodków miejskich Opola, Szczecina, Olsztyna, Lublina dominują ośrodki miejskie umiarkowanego wzrostu charakteryzujące się zmiennym trendem, lub miasta typu regresywnego. W ośrodkach tych mamy do czynienia nie tylko z tendencją umiarkowanego wzrostu obszarów podmiejskich, lecz także z podobną sytuacją w przypadku miast centralnych. W badanym okresie ośrodki rdzenia charakteryzowały się wzrostem demograficznym do końca XX w., a następnie powolnym spadkiem liczby ludności od 1999 r. (Opole, Szczecin, Lublin) czy 2009 r. (Olsztyn). Na Białorusi ośrodki miejskie tego typu są najbardziej rozpowszechnione i położone w peryferyjnych częściach wszystkich obwodów. W tej grupie znajdują się największe ośrodki przemysłowe - Bobrujsk, Borysów, Molodeczno.

Niekorzystną dynamiką rozwoju demograficznego charakteryzują się obszary metropolitalne Łodzi i Katowic, w obu przypadkach mamy do czynienia z depopulacją miasta centralnego, a także występowaniem regresji demograficznej 
w miastach małych, położonych w granicach obszaru metropolitalnego. Taki rodzaj dynamiki rdzenia i obszarów podmiejskich na Białorusi charakterystyczny jest tylko dla Witebska.

Jeżeli chodzi o ośrodki miejskie położone poza obszarami metropolitalnymi, to największy potencjał demograficzny cechuje małe miasta położone w Wielkopolsce oraz miasta położone w środkowo-wschodniej części Małopolski. Na większości obszaru tych województw występowały miasta o korzystnej dynamice ludności. Małe ośrodki miejskie o korzystnej dynamice liczby ludności znajdowały się również w północno-zachodniej części województwa lubuskiego. Tendencję wzrostu liczby ludności małych miast zaobserwowano w wybranych ośrodkach turystycznych Pojezierza Mazurskiego, Pomorskiego oraz Pobrzeża. Na Białorusi korzystna dynamika ludności w ośrodkach miejskich położonych poza obszarami metropolitalnymi występuje w niektórych dużych miastach przemysłowych (Baranowicze, Żlobin, Sologorsk) oraz w małych miastach, które są centrami terenów rolniczych, zachowały swój profil funkcjonalny i utrzymały stabilność demograficzną. Wśród stabilnych małych miast większość stanowią ośrodki rolnicze na południowym zachodzie Białorusi i pojedyncze występują w obszarach metropolitalnych.

Niekorzystne tendencje demograficzne i występowanie zwartych obszarów charakteryzujących się depopulacją zaobserwowano na terenie południowej części województwa dolnośląskiego i opolskiego, a także w pasie południowej części województwa łódzkiego, północnej świętokrzyskiego i południowej województwa lubelskiego. Nasilenie procesu depopulacyjnego w tej części kraju może doprowadzić do przenoszenia się części mieszkańców do większych ośrodków miejskich oraz utraty bazy ekonomicznej miast małych i średnich analizowanych regionów. $\mathrm{Na}$ Białorusi niekorzystne tendencje demograficzne w ośrodkach miejskich w całym okresie badawczym zaobserwowano w małych miastach położonych peryferyjnie.

\section{Literatura}

Amin A., Thrift N., 1994, Globalization, institutions, and regional development in Europe, Oxford University Press, Oxford.

Antipova E., Fakeyeva L. 2012 Settlement system of Belarus. Spatial and temporal trends at the end of 20th and the beginning of the 21st centuries, Journal of Settlements and Spatial Planning, 3, (2), 129-139.

Berg L. van den, Drewett R., Klaassen L.H., Rossi A., Vijverberg C.H.T., 1982, Urban Europe. A Study of growth and decline. 1, Oxford: Pergamon Press.

Bieńkowska E., 2013, Depopulacja jako wyzwanie dla polskiej polityki miejskiej, [w:] N. Szajewska, M. Lipińska (red.), Zarzqdzanie rozwojem miast o zmniejszajqcej się liczbie mieszkańców (w kontekście perspektywy finansowej 2014-2020), Senat Rzeczypospolitej Polskiej, Kancelaria Senatu, Warszawa, 11-19. 
Champion A. G., 2001, A changing demographic regime and evolving polycentric urban regions: Consequences for the size, composition and distribution of city populations, Urban Studies, 38 (4), 657-677.

Conti S., 1997, Interpendent and uneven development. A systemic view of the global-local dialectic, Bulletin 47 (2), International Geographical Union, 195-204.

Dicken P., 1994, Global-local tension: firms and states in the global space-economy. The Roepke Lecture in Economic Geography, Economic Geography, 70 (2), 101-128.

Długosz Z., 2005, Population movements in large Polish cities in 1988-2002, Bulletin of Geography, Socio-economic Series, 4, 25-36.

Domański R., 2006, Gospodarka przestrzenna. Podstawy teoretyczne, PWN, Warszawa.

Eberhardt P., 1989, Regiony wyludniajqce się w Polsce, Prace Geograficzne, IGiGPZ PAN, 148.

Gurin N., 1984, Problemy pereustroystva selskogo rasseleniya v zonah vliyaniya krupnyih gorodov (na primere g. Minska), BGU, Minsk. In: Гурин, Н.Н. Проблемы переустройства сельского расселения в зонах влияния крупных городов (на примере г. Минска): автореф. дис. ... канд. геогр. наук 11.00.02 / Н.Н. Гурин; БГУ им. В.И. Ленина. - Минск, 1984. - 21 с.

Jakóbczyk-Gryszkiewicz J., 2011, Ewolucja procesów suburbaniæacji w regionie miejskim Łodzi, [w:] J. Jakóbczyk-Gryszkiewicz (red.), Regiony miejskie w Polsce, 20, 89-116.

Jałowiecki B., Gorzelak G., Smętkowski M., 2009, Obsæary metropolitalne w Polsce - diagnoza i rekomendacje, Studia Regionalne i Lokalne, 1, 35, 52-73.

Kabisch N., Haase D., Haase A., 2012, Urban population development in Europe, 1991-2008: The examples of Poland and the UK, International Journal of Urban and Regional Research, 36 (6), 1326-1348.

Kantor-Pietraga I., Krzysztofik R., Runge J., 2012, Kontekst geograficzny i funkcjonalny kurczenia się matych miast w Polsce potudniowej, [w:] K. Heffner, A. Halama (red.) Ewolucja funkcji matych miast w Polsce, Studia Ekonomiczne Zeszyty Naukowe Wydziałowe Uniwersytetu Ekonomicznego, Wydawnictwo Uniwersytetu Ekonomicznego w Katowicach, Katowice, 9-24.

Kantor-Pietraga I., 2014, Systematyka procesu depopulacji miast na obszarze Polski od XIX do XXI wieku, Wydawnictwo Uniwersytetu Śląskiego, Katowice.

Klaassen L. H., Scimeni G., 1981, Theoretical issues in urban dynamic, [w:] L.H. Klaassen, W.T.M. Molle and J. H. P. Paelinck (red.), Dynamic of urban development, Aldershot: Gower, $8-28$.

Klunia W., 2000, Ekonomicheskie problemyi razvitiya agropromyishlennogo kompleksa v usloviyah perehodnoy ekonomiki, BGU, Minsk. In: Клюня, В.Л. Экономические проблемы развития агропромышленного комплекса в условиях переходной экономики: автореф. дис. ... д-ра эк. наук: 08.00.01/ В.Л. Клюня, Белорусский государственный университет. - Минск, 2000. -34 c.

Krasowski K., 2004, Urbanizatsiya v Belarusi: ekonomiko-geograficheskiy analiz, BrGU, Brest. In: Красовский, К.К. Урбанизация в Беларуси: экономико-географический анализ / К.К. Красовский. - Брест: Изд-во БрГУ, 2004. - 203 с. 
Krasowski K., 2006, Urbanizatsiya v Belarusi: ekonomiko-geograficheskiy analiz i prognoz. BGU, Minsk. In: Красовский, К.К. Урбанизация в Беларуси: экономико-географический анализ и прогноз: автореф. дис. ... Д-ра геогр. наук: 25.00.24 / К.К. Красовский; Белор. гос. ун-т. - Минск, 2006. -44 с.

Kroll F., Kabisch N., 2012, The relation of diverging urban growth processes and demographic change along an urban-rural gradient, Population, Space and Place, 18 (3), 260-276.

Kurek S., 2005, Territorial distribution of population change in Poland in the years 1991-2001, Bulletin of Geography, Socio-economic Series., 4, 117-133.

Manak B.A., 1992, Naselnitstua Belarusi: regiyanalnyiya asablivastsi razvitstsya i rassyalennya, Universitetskae, Minsk. In: Манак, Б.А. Насельніцтва Беларусі: рэгіянальныя асаблівасц $i$ развіцця $i$ рассялення / Б.А. Манак. - Мн.: Універсітэцкае, 1992. - 176 с.

Manak B.A., Antipova E. A., 1999, Ekonomiko-geograficheskiy analiz demograficheskoy situatsii i razmescheniya naseleniya na territorii Respubliki Belarus, BGU, Minsk. In: Манак, Б.А. Экономико-географический анализ демографической ситуации и размещения населения на территории Республики Беларусь / Б.А. Манак, Е.А. Антипова. - Мн: БГУ, 1999. - 291 с.

Maksimow G., 1972, Izuchenie sistemyi gorodskih poseleniy BSSR metodami matematicheskoy stati$s t i k i$, Nauka i tehnika, Minsk. In: Максимов, Г.Т. Изучение системы городских поселений БССР методами математической статистики / Г.Т. Максимов. - Мн.: Наука и техника, 1971. - $160 \mathrm{c}$.

Markowski T., Marszał T., 2006, Metropolie, obszary metropolitalne, metropolizacja. Problemy i pojecia podstawowe, KPZK PAN, Warszawa.

Medwedew W., Polskiy S., 1969, Planirovanie i regulirovanie rosta gorodov (Belorusskaya SSR), NII ekonomiki i ekonomiko-matematicheskih metodov planirovaniya pri Gosplane BSSR, Minsk. In: Медведев В.Ф., Польский С.А. Планирование и регулирование роста городов (Белорусская ССР): НИИ экономики и экономико-математических методов планирования при Госплане БССР, Минск, 1969.

Miszewska B.,1998, Badania sieci osadniczej w ośrodku wroctawskim, [w:] J. Kaczmarek (red.), Metodologia geografii osadnictwa na przełomie wieków. X Konwersatorium wiedzy o mieście, Wydawnictwo Uniwersytetu Łódzkiego, Łódź, 71-95.

Mykhnenko V., Turok I. 2008, East European cities-patterns of growth and decline, 1960-2005, International Planning Studies, 13 (4), 311-342.

Parysek J., 2005, Development of Polish towns and cities and factors affecting this process at the turn of the century, Geographia Polonica, 78 (1), 99-116.

Pirozhnik I., 2000, Prostranstvennyie aspektyi urbanizatsii Belarusi, Vestnik BGU. Seriya 2. Himiya. Biologiya. Geografiya, 3, 77 - 82. In: Пирожник, И.И. Пространственные аспекты урбанизации Беларуси / И.И. Пирожник // Вестник БГУ. Серия 2. Химия. Биология. География. - 2000. - № 3. - С. 77-82.

Pirozhnik I., Antipova E., 2006, Transformatsiya sistemyi rasseleniya Belarusi vo vtoroy polovine $X X$ - nachale XXI v., Vestnik BGU. Seriya 2. Himiya. Biologiya. Geografiya, 3, 72-78. In: Пирожник И.И., Антипова Е.А. Трансформация системы расселения Беларуси во второй 
половине $X X$ - начале $X X I$ в. // Вестник БГУ. Серия 2. Химия. Биология. География. 2006. - № 3. - C. 72-78.

Pirozhnik I., Antipova E., 2013, Prostranstvennaya struktura gorodskogo rasseleniya $i$ harakter urbanizatsii Belarusi v usloviyah globalizatsii, Regionalnyie issledovaniya, 40 (2), 82-93. In: Пирожник И.И., Антипова Е.А. Пространственная структура городского расселения и характер урбанизации Беларуси в условиях глобализации // Региональные исследования, № 2(40), 2013. - c. 82-93.

Polskiy S. (red.), 1973, Gorod i mayatnikovaya migratsiya naseleniya, NII ekonomiki i ekonomikomatematicheskih metodov planirovaniya pri Gosplane BSSR, Minsk. In: Город и маятниковая миграция населения // под ред. С.А. Польского.- Мн.: НИИ экономики и экономикоматематических методов планирования при Госплане БССР, 1973. - 185 с.

Polskiy S., 1976, Demograficheskie problemyi razvitiya Minska, BGU, Minsk. In: Польский, С.А. Демографические проблемы развития Минска / С.А. Польский; под. ред. Ю.К. Козлова. - Минск: БГУ, 1976. - 152 с.

Potrykowska A., 1989, Procesy depopulacji obszarów wiejskich w Polsce, Czasopismo Geograficzne, 60 (4), 405-416.

Rakow A., 1969, Naselenie BSSR,Vyisheyshaya shkola, Minsk. In: Раков, А.А. Население БССР / А.А. Раков. - Минск: Вышэйшая школа, 1969. - 223 с.

Rakow A., 1974, Belorussiya v demograficheskom iæmerenii, Minsk. In: Раков А. А. Белоруссия в демографическом измерении, Минск, 1974 - 127с. (Библиотечка газеты «Голас Радзімы»).

Rink D., Couch C., Haase A., Krzysztofik R., Nadolu, B., Rumpel, P., 2014, The governance of urban shrinkage in cities of post-socialist Europe: policies, strategies and actors, Urban Research \& Practice, 7 (3), 258-277.

Runge A., 2012, Metodologicæne problemy badania miast średnich w Polsce, Prace Geograficzne, 129, 83-101.

Runge J., 2007, Metody badań w geografii spoteczno-ekonomicænej-elementy metodologii, wybrane narzędzia badawcze, Wydawnictwo Uniwersytetu Śląskiego, Katowice.

Sassen S., 2001, The global city: New York, London, Tokyo, Princeton University Press.

Shakhotska L., 1975, Rozhdaemost v Belorussii: sotsialno-ekonomicheskievoprosyi, Nauka i tehnika, Minsk. In: Шахотько, Л. П. (1975). Рождаемость в Белоруссии: социально-экономические вопросы. - Минск: Наука и техника, 1975. - 167 с.

Shakhotska L., 1985, Vosproizvodstoo naseleniya Belorusskoy SSR, Nauka i tehnika, Minsk. In: Шахотько, Л.П. Воспроизводство населения Белорусской ССР / Л.П. Шахотько; под ред. А.А. Ракова. Минск: Наука и техника, 1985. - 128 с.

Sidorow P., Maksimow G., 1966, Rol migratsii v izmenenii chislennosti gorodskogo naseleniya Belorusskoy SSSR: (Opyt rascheta na ETSVM» Minsk-2» po algoritmu i programme faktornogo analiza) NII ekonomiki i ekonomiko-matematicheskih metodov planirovaniya pri Gosplane BSSR, Minsk. In: Сидоров, П. А., Максимов, Г. Т. Роль миграции в изменении численности городского населения Белорусской СССР: (Опыт расчета на ЭЦВМ „Минск-2” по алгоритму и программе факторного анализа). Минск: НИИ экономики и экономикоматематических методов планирования при Госплане БССР, 1966. - 37 с. 
Smętkowski, M., Jałowiecki, B., Gorzelak G., 2009, Obszary metropolitalne w Polsce-diagnoza i rekomendacje, Studia Regionalne i Lokalne, 1, 52-73.

Steinführer, A., Haase, A., 2007, Demographic change as a future challenge for cities in East Central Europe, Geografiska Annaler: Series B, Human Geography, 89 (2), 183-195.

Storper M., Scott A., 1992, Pathways to industrialization and regional development, Routledge, London, New York.

Sýkora, L., Bouzarovski, S., 2012, Multiple transformations conceptualising the post-communist urban transition, Urban Studies, 49 (1), 43-60.

Szymańska D., Grzelak-Kostulska, 2005a, Mate miasta w Polsce - smiany funkcjonalne i ludnościowe w drugiej potowie XX wieku, [w:] Heffner K. (red.), Mate miasta a rozwój lokalny i regionalny, Wyd. Akademii Ekonomicznej w Katowicach, Katowice, 59-90.

Szymańska D., Grzelak-Kostulska, 2005b, Problematyka matych miast w Polsce w świetle literatury, [w:] K. Heffner, T. Marszał (red.), Problemy rowwoju małych miast w wymiarze lokalnym i regionalnym, Biuletyn Komitetu Przestrzennego Zagospodarowania Kraju PAN, Warszawa, 220, 21-36.

Szymanska D., Matczak A., 2002, Urbanization in Poland: Tendencies and transformation, European Urban and Regional Studies, 9 (1), 39-46.

Zborowski A., 2005, Præemiany struktury społeczno-præestrzennej regionu miejskiego w okresie realnego socjalizmu i transformacji ustrojowej (na przyktadzie Krakowa), Instytut Geografii i Gospodarki Przestrzennej, Uniwersytet Jagielloński, Kraków.

Zborowski, A., Chaberko, T., Kretowicz, P., 2011, Procesy suburbanizacji rezydencjonalnej w regionie miejskim Krakowa: przemiany spoteczno-przestrzenne. Regiony miejskie w Polsce. Dwadzieścia lat transformacji, Wydawnictwo Uniwersytetu Łódzkiego, Łódź, 89-116.

Zborowski A., Soja M., Łobodzińska A., 2012, Population trends in Polish cities - stagnation, depopulation or shrinkage?, Prace Geograficzne, 130, 7-28.

\section{Źródła danych}

Demographical statistical yearbook of Belarus, 2014-Minsk: National Statistical Committee, 2014, 1-412.

Demographical statistical yearbook of Poland, 2014 - Warsaw: Central Statistical Committee, 2014, 1-600.

Liudmila Fakeyeva

Fakultet Relacji Międzynarodowych, Biatoruski Universytet Państwowy

ul. Leningradskaya 20, Mińsk

fokeeva@bsu.by

Katarzyna Gorczyca

Uniwersytet Jagiellonski

Instytut Geografii i Gospodarki Przestrzennej

ul. Gronostajowa 7, 30-387 Kraków

k.gorczyca@uj.edu.pl
Andræej Zborowski Uniwersytet Jagiellonski

Instytut Geografii i Gospodarki Przestrzennej ul. Gronostajowa 7, 30-387 Kraków andræej.zborowski@uj.edu.pl 